\title{
Representativeness in Geographical Indications: A Comparison between the State-Driven and Producer-Driven Systems in Vietnam and France
}

\author{
Barbara Pick * and Delphine Marie-Vivien
}

check for updates

Citation: Pick, B.; Marie-Vivien, D. Representativeness in Geographical Indications: A Comparison between the State-Driven and ProducerDriven Systems in Vietnam and France. Sustainability 2021, 13, 5056 https://doi.org/10.3390/su13095056

Academic Editor: Giovanni Belletti, Andrea Marescotti, Filippo Arfini,

François Casabianca, Emilie

Vandecandelaere and Junko Kimura

Received: 14 March 2021

Accepted: 9 April 2021

Published: 30 April 2021

Publisher's Note: MDPI stays neutral with regard to jurisdictional claims in published maps and institutional affiliations.

Copyright: (c) 2021 by the authors. Licensee MDPI, Basel, Switzerland. This article is an open access article distributed under the terms and conditions of the Creative Commons Attribution (CC BY) license (https:/ / creativecommons.org/licenses/by/ $4.0 /)$.
CIRAD, INRAE, Institut Agro, UMR INNOVATION, Université de Montpellier, F-34398 Montpellier, France; delphine.marie-vivien@cirad.fr

* Correspondence: B.I.Pick@lse.ac.uk

\begin{abstract}
This paper explores the issues of representativeness and participation in the collective processes involved in the elaboration of the geographical indications (GI) specifications and the governance of the GI initiatives. The objective is to understand the relationship among collective dynamics, representativeness of relevant stakeholders, and the legal frameworks for the protection of GIs. Using a qualitative methodology based on an analysis of six case studies in France and Vietnam, we show the role of the law in shaping the different ways of understanding and implementing the concept of representativeness in the French producer-led and the Vietnamese state-driven approaches to GI protection. In France, the GI specifications result from negotiations among all legitimate stakeholders, which may prove long, complex, and lead to standards that can continue to be challenged after the GI registration. We also argue that the rules for the representation of all GI users in the decision-making processes do not necessarily lead to fairness. In Vietnam, local stakeholders usually have a consultative role under the authority of the State, resulting in their little understanding and low use of the GI. Their empowerment is further hindered by the involvement of state authorities in the management of the producers' associations. We conclude by discussing in-between solutions to promote the producers' representation and participation.
\end{abstract}

Keywords: geographical indications; representativeness; collective dynamics; legal frameworks; producers' groups; state-driven; producer-driven; specifications; Vietnam; France

\section{Introduction}

Geographical indications (GIs) 'identify a good as originating in the territory of a Member, or a region or locality in that territory, where a given quality, reputation or other characteristic of the good is essentially attributable to its geographical origin'(Article 22.1, Agreement on Trade Related Aspects of Intellectual Property Rights, 15 April 1994, Annex 1C of the Marrakesh Agreement Establishing the World Trade Organization). Some wellknown GI products include Darjeeling tea, Parma ham, Champagne wine, and Café de Colombia. These are only a few examples of the many place-based products that have enjoyed great commercial success long before the formal definition of GIs by the WTO Agreement on Trade-Related Aspects of Intellectual Property Rights (TRIPS). Very few countries had enacted legislation for protecting GIs prior to the adoption of TRIPS (WIPO. The Definition of Geographical Indications; WIPO, October 2002 (SCT/9/4), p. 4). Laws governing the use of GIs have subsequently mushroomed around the world, but in the 'most diverse and uncoordinated manner' [1] (pp. 264-265), resulting in significant divergences in the modes of protection [2,3]. Today, there are estimated to be about 56,000 protected GIs in the world, including 55.9\% in Europe, followed by Asia (32\%), Latin America and the Caribbean (5.6\%), Oceania (3.8\%), North America (2.5\%), and Africa $(0.3 \%)$ [4]. 
The concept of a link between a product and its place of origin stems from the French appellation d'origine contrôlée (AOC) system [5], which has modelled the European concept of protected denominations of origin (PDOs). The AOC system is fundamentally based on the concept of terroir, which emphasizes the importance of both natural factors (geographical milieu including soil, climate, etc.) and human factors (the producers' knowhow, methods, etc.) for the definition of GI products and their link to origin. In European law, PDOs are names identifying products 'whose qualities or characteristics are essentially or exclusively due to a particular geographical environment with its inherent natural and human factors' (Article 5.1, Council Regulation (EU) No 1151/2012 of the European Parliament and of the Council of 21 November 2012 on quality schemes for agricultural products and foodstuff). As such, AOCs and PDOs are closely associated with cultural, social, and environmental values. The EU also introduced the concept of protected geographical indications (PGIs). The definition of PGIs echoes that of GIs provided by TRIPS and allows for a more flexible link to origin that does not require the combination of natural and human factors (Article 5.2, Council Regulation (EU) No 1151/2012).

Because GIs signal origin, they have close ties with places, and their elaboration typically relies on the local resources, knowledge, skills, practices, history, and culture of a community of people within a specific geographical area [6]. Mobilization and coordination among these various actors are necessary for the formulation and harmonization of the production norms, quality standards, and trading practices. These collective and voluntary norms aim to protect the common good, i.e., the product's reputation and hence to build and maintain consumer trust.

Unlike other certification schemes such as fair trade and organic farming where the norms of the certification are designed in a top-down fashion and have almost the same content across the world regardless of the specificities of the local contexts, GI protection aims to provide local actors with a space to discuss their own vision of the product, including its description, quality, characteristics, and production process as well as the delimitation of the geographical area [7]. By enabling local stakeholders to build their own rules [8-10], each GI relies on unique product specifications which reflect a "can-do spirit" [11] (p. 2996). The strong collective dimension of GIs has been captured by the law which usually considers GI protection as a form of collective legal monopoly right that can only be used by those stakeholders who are located inside the region and who satisfy the standards defining the product in its specifications [12]. At the same time, the variety of legal frameworks for the protection of GIs has translated in different roles assigned to local stakeholders and state authorities in the registration process and the management of the GI producers' organizations across countries depending on whether they have adopted a state-driven or producer-led approach to GI protection [13].

The collective processes involved in the elaboration of the GI specifications and the governance of the GI initiatives lead us to address the critical issues of representativeness and participation in light of the legal framework. For example, local stakeholders may disagree and negotiate over which methods of production, plant varieties, agricultural practices, product name, or boundaries to codify in the GI specifications [14], thereby revealing asymmetrical bargaining power between different actors $[15,16]$. The decisionmaking process may have exclusionary effects in respect of those who are unwilling or unable to comply with these specifications, especially the small-scale or traditional producers who often build the image of the GI. Such exclusionary effects reflect a trade-off between inclusiveness and economic success linked to an 'exclusivity strategy' [17] (p. 21). Whereas a number of scholars have studied collective action dynamics during GI registration processes [18], including how conflicts arise and get solved [19], very few authors have studied the relationship between, on the one hand, the conflicts among stakeholders and, on the other hand, the governance of GIs and the extent to which it is representative and inclusive of all legitimate GI users [11]. In particular, the controversies among stakeholders were found to depend on how the decisions were made and the extent 
to which the decision-making process ensured the representativeness and the inclusion of the various actors involved [11].

The objective of this paper is to build upon this research by exploring the relationship between collective dynamics and the national legal frameworks for the protection of GIs.

More specifically, it aims to understand the impact of national laws on the representation, inclusion, and participation of local actors in the GI producers' groups and in the elaboration process of the product specifications. To provide valuable insights on the causal relationships between the law and collective dynamics, this paper involves a comparative case study strategy to contrast and analyze the state-driven and producer-led approaches to GI protection. How do these two systems shape the concept of representativeness during the process of establishing the GI collectives and drawing up the GI specifications?

Using a qualitative methodology, this paper is based on a comparative analysis of six case studies in France and Vietnam. The choice to investigate GI initiatives in these two countries was made considering the contrasting roles assigned by law to local stakeholders and state authorities in the registration process and the management of the GI producers' organizations in both countries. While, pursuant to the law in each of these countries, French producers have a pivotal role in initiating the GI protection process, elaborating the GI specification, and managing the GI producers' organizations, albeit with the support of state authorities, in Vietnam, these processes are primarily led by the State. As such, France and Vietnam are representative of the producer-led and state-driven approaches to GI protection, which enables to explore whether and how these two systems lead to different understandings of the concept of representativeness and impact differently on collective dynamics.

The case studies were selected randomly to cover a variety of products including agricultural products that have undergone little or no processing, foodstuffs resulting from the processing of unprocessed products, and handicrafts, as follows:

- Vietnam: Star anise from Lạng Son (GI since 2007); Conical hat from Huế (GI since 2010); Fried calamari from Hạ Long (GI since 2013);

- $\quad$ France: Green lentils from Berry (PGI since 1998); Pélardon cheese (AOC in 2000; PDO since 2001); Bouchot mussels from Mont-St-Michel Bay (AOC in 2006; PDO since 2011).

Primary data were collected through semi-structured interviews that were conducted in France and Vietnam in 2014 and by telephone and email communications in 20172020. The interviews aimed primarily to generate explanations about how GI producers' groups were established and how consensus was reached during the establishment phase, including the main issues of contention during the negotiations of the GI technical rulesor else, the extent to which the decision-making process was participatory. Interviewees included (1) public authorities; (2) farmers, producers, and processors; (3) distributors and traders; and (4) leaders of producers' associations and cooperatives. Overall, we conducted between 6 and 10 interviews for each GI product for a total of 42 interviews. Secondary data were generated through desk study of legal texts, product specifications, registration regulations, statutes of the GI collective organizations, and evaluation reports. Each case was analyzed individually before comparing them with and among each other to highlight commonalities and differences. As part of this process, interview transcripts and document-generated data were coded manually. Secondary data were also generated for cases such as Camembert de Normandie and fish sauce from Phu Quoc.

Section 2 analyzes how the concept of representativeness is addressed in the legal frameworks for protecting GIs in France and Vietnam. Section 3 presents different case studies to explore how the different understandings of the concept of representativeness in each national legal framework impact on the constitution and representation of the producers' groups and affect the elaboration process of the product specifications. Section 4 discusses some of the issues arising out of the forms and processes of collective action in each country as influenced by the legal environment and which challenge the concept of representativeness. 


\section{Representativeness in French and Vietnamese GI Law}

The GI applicant is crucial in determining the objectives associated with the GI protection and the content of the product specifications. However, the TRIPS Agreement does not specify who can submit an application for GI protection, nor do other international agreements such as the Lisbon agreement and its Geneva Act for the international protection of appellations of origin and geographical indications. The nature of the applicant thus varies across countries. Two approaches are commonly used: Applications may be prepared and submitted by a group of producers only like in France and other European countries, or they may be submitted by a public authority. This is the case in Vietnam, where it is mandatory by law and in other countries who have only recently adopted GI provisions to comply with TRIPS [20] such as India [21], Indonesia [22], and other ASEAN countries [23]. Unlike in France where protection of GIs has matured for over a century out of a long process that was initiated by local producers, the legal framework for GIs in Vietnam is fairly recent and was led by state authorities. The state-driven, top-down approach of Vietnam to protecting GIs sharply contrasts with the bottom-up system of GI protection in France, which has important consequences on the way in which the concept of representativeness is understood and applied.

\subsection{Bottom-Up and Producer-Driven Approach in Europe/France}

In Europe, where only those stakeholders who are complying with the specifications have the right to use the PDO/PGI and the official PDO or PGI logos (Regulation 1151/2012, Article 12.1.), the specifications are a strategic tool that may have exclusionary effects deriving from the definition of the geographical area or the conditions of production [24]. Therefore, the collective action of local operators is fundamental to initiate the application process for GI protection. According to Article 49.1 of Regulation 1151/2012, PDO/PGI applications 'may only be submitted by groups who work with the products', with groups being defined as 'any association, irrespective of its legal form, mainly composed of producers or processors working with the same product' (Regulation 1151/2012, Article 3(2)). No criterion of representativeness or inclusiveness is included in this definition, yet only groups with a 'legitimate interest' are eligible to apply for approval of an amendment to the product specification (Regulation 1151/2012, Article 53.1).

In French law, an Order adopted in 2006 (Ordonnance 12006-1547 du 7 décembre 2006 relatif à la valorisation des produits agricole, forestiers ou alimentaires et des produits de la mer (Order of 7 December 2006 for the promotion of agricultural, forestry, food and seafood products) (8 décembre 2006) JO 18607) stipulates that all operators involved in the production, processing, elaboration, and packaging of the product (Rural Code, Article L.642-3) must group together within one single entity with legal personality (Rural Code, Article L.642-17). Such an entity, to which all operators must necessarily adhere to be given the right to use the GI (Rural Code, Articles L.642-3 and L.642-21), must be recognized by the French national institution for the recognition of PDOs/PGIs (Institut National de l'Origine et de la Qualité, INAO) as an Organization for the Defense and Management of the PDO/PGI (Organisme de Défense et de Gestion, ODG) (Rural Code, Article L.642-17) on the basis of (i) its representativeness and (ii) the balanced representation of the different professional groups involved (Rural Code, Article L.642-18). These two requirements, which are not mentioned in European law, aim to ensure the democratic functioning and inclusivity of the producers' organizations (INAO. Guide du demandeur pour la reconnaissance en qualité d'organisme de défense et de gestion; INAO, Janvier 2016; p. 10). To assess the representativeness of the ODGs, information shall be provided on the number of operators who are already members of the candidate body and the volumes they produce as compared with the total production volume (Ibid.). For example, it was found that the Organization for "Limoges porcelain", which represents 75\% of operators and 90\% of turnover in this sector, is representative of all the stakeholders involved with this product (Court of Appeal of Paris 25 Sept. 2018). Besides, to ensure the democratic functioning of the ODG, all members shall have the right to participate in its general assemblies, taking into account that quorum rules 
for decision-making should guarantee their proportional representation (INAO (n15), p. 11). Finally, all the different professional groups involved, including producers, processors, and packagers, should be equally represented in all decision-making bodies, including the board of directors and the general assembly (Ibid., p. 12).

The ODGs are generally responsible for managing the GI. They should, among others, elaborate the product specifications and contribute to their implementation; participate in the elaboration of the control plan in collaboration with the certification body; participate in the implementation of internal controls; identify and update the list of local operators and ensure the periodic transmission of this information to both INAO and the certification body; participate in activities related to the defense and management of the appellation, the product, and the terroir as well as in the promotion of the product and in the statistical knowledge of the sector; implement the relevant decisions of INAO's national committee; and provide INAO with any information collected in connection with their missions, upon request (Statutes of the ODGs 'Lentilles vertes du Berry', 'Moules de Bouchot de la Baie du Mont-Saint-Michel' and 'Pélardon', Article 2). Applications for GI protection, including the product specifications, must be submitted by the ODGs (Rural Code, Article L.641-6), thereby giving local operators grouped within an association a key role in the initiation of the application process. As a normative document that codifies the product quality and cultural and agro-environmental practices, the product specifications are generally regarded as the masterpiece of representative collective action as it must be agreed upon collectively by producers and other relevant stakeholders [25], which highlights their pivotal role in the definition of the products. Despite their mandatory content, the product specifications allow for some flexibility and can vary greatly in terms of details and standards across PDO/PGI products. Local stakeholders taking part in the elaboration process are ultimately the ones deciding which criteria and rules of production to includeor deliberately ignore. Even if there is mediation from the State, as does INAO in France, producers are the ones who ultimately make the decisions.

\subsection{Top-Down and State-Driven Approach in Vietnam}

By contrast to the bottom-up and producer-driven process in France, the identification of the product candidates for GI protection in Vietnam and their ensuing registration and management are primarily the responsibility of the state, which thereby establishes itself as representative of the local stakeholders.

In Vietnam, the owner of all GIs is the State (IP Law, Article 121.4) and the right to register GIs with the National Office of Intellectual Property (NOIP) belongs to the State who can allow organizations/individuals involved in the production of the product, their representative collective organizations, or the administrative authorities of the locality to which the product pertains, to exercise this right (IP Law, Article 88). In practice, no GI has been registered by producers or collective organizations to date, the only exception being for the Nuoc Mam (fish sauce) from Phu Quoc (probably because Nuoc Mam Phu Quoc was developed through a cooperation project with France and the EU). Public authorities generally recruit a technical expert to proceed with the registration of the GI under their supervision. As part of the application process, the technical expert should provide the name or sign to be protected as a GI (Vietnamese law protects only the name or sign that constitutes the GI itself, i.e., not the combination of the name or sign with the type of product), a map of the geographical area corresponding to the GI (IP Law, Article 106.1), and a detailed document describing the peculiar characteristics of the product (IP Law, Article 106.2). Unlike in France and other EU Member States where official PDO/PGI labels are the same for all protected products, there is no one official state logo for all GIs as yet in Vietnam. In practice, the technical expert in charge of the GI registration usually oversees the design of the logo for that particular GI product, with each GI having a specific logo (IP Law, Article 106-1(a)).

Unlike in France, there is no obligation under Vietnamese law for local stakeholders to organize themselves within one single association, hence membership in the producers' 
association is not a legal requirement. However, depending on each GI, it can be chosen to establish a producers' association. If so decided, the technical expert in charge of the GI registration is usually responsible for the establishment of an association of producers, processors, and/or traders as well as training of farmers/producers in production technics; the organization of the supply chain; and awareness and communication activities. It is typically not until the implementation phase of the projects that local stakeholders become involved in the initiatives.

Consequently, unlike in France where the creation of the GI initiatives is largely based on the collective, voluntary, and participatory action of local stakeholders, in Vietnam, collective action dynamics do not usually precede the creation of associations but rather are instigated by an external expert under the supervision of state authorities. The creation process of producers' associations is thus largely technocratic following a top-down, statedriven approach to protecting GIs. Unlike in French law, Vietnamese law is silent on the quorum and voting rules within the producers' associations. Depending on each GI, membership can be made a mandatory condition for being granted the right to use the GI.

While the missions of the French ODGs are centered around the defense of the appellations, in Vietnam, the GI producers' associations are clearly market-oriented. According to the NOIP, they should, among others, coordinate the purchase and distribution of the products of the members of the association; organize promotion and marketing activities; manage, monitor, guide, and control the cultivation, processing, and marketing processes (internal control); and manage the use of the logos and packaging (NOIP. Guide à la construction du projet "Gestion et Développement des IGs"; NOIP, 2009; pp. 15-16).

The ownership of all GIs provides the State with the right to manage GIs (IP Law, Article 121.4), which includes the right to authorize the use of GIs (IP Law, Article 123.2(a)). The right to manage can also be transferred to a representative organization of all collectives and individuals conferred with the right to use the GI (IP Law, Article 121.4). The right to use the GI can be granted to organizations or individuals located in the relevant area and involved in the production and marketing of the GI product (IP Law, Article 121.4). Local stakeholders must apply individually to the management organization to obtain the right to use the GI. It is the only right that can be granted to local stakeholders who are not associated with the registration procedure nor the management system.

\section{The Impacts of the Producer-Driven versus State-Driven Processes on Shaping the Concept of Representativeness: Case Studies in France and Vietnam}

This section explores the creation process of GI initiatives in six case studies in France and Vietnam. The objective is to better understand how the different understandings of the concept of representativeness in the producer-driven and state-driven systems (i) impact on the collective action of producers (constitution and representation of the producers' groups); and (ii) affect the elaboration process of the product specifications.

\subsection{Constitution and Functioning of the GI Producers' Groups}

France's bottom-up approach to protecting GIs versus Vietnam's state-driven policy provide important clues to understand the contrasting active and passive roles of local stakeholders in the creation process of GI collectives in each country.

3.1.1. Representation and Active Participation of All Local Stakeholders Involved with the GI Product

In France, PDO/PGI applications must be submitted by an ODG, which must be created before the PDO/PGI application. In practice, collective action dynamics often precede the creation of ODGs, which must implement a very demanding form of collective action complying with the criterion of representativeness of all professional groups involved. For instance, Pélardon producers created a first union in 1987, which became the Association for the Defence of Pélardon in 1993, before they decided to apply for a PDO recognition in 1994. Likewise, lentil producers created the association 'Lentilles vertes du Berry' in 1994, two years before they decided to apply for a PGI. In both cases, the producers' association 
became the ODG, which required amending its statutes to change the association's name, missions, and membership. For example, to be recognized as the representative ODG for green lentils from Berry, the association created in 1994 among a dozen farmers had to open its membership to three other types of stakeholders: Storage silos; wholesalers-packers; and the sorting center [26]. (Statutes of the ODG 'Lentilles vertes du Berry', Article 5).

In the case of the Bouchot mussels from Mont-St-Michel Bay, producers interacted and defended different interests in three professional unions created between 1971 and 2002. The qualification process brought together producers from the three unions in one ODG created in 2003, which thus emerged as a unifying association. The size of the ODGs can vary greatly from a dozen to hundreds of members. In the case studies presented in this paper, the ODGs for green lentils from Berry, Pélardon cheese, and mussels from the Mont St Michel Bay gather 59, 72, and 123 members, respectively (see Table 1).

Table 1. Composition of the geographical indications (GI) producers' groups in six case studies in France and Vietnam.

\begin{tabular}{cccc}
\hline Country & Product & $\begin{array}{c}\text { Professional Groups among } \\
\text { Members }\end{array}$ & Membership \\
\hline France & $\begin{array}{c}\text { Bouchot mussels from the } \\
\text { Mont-St-Michel Bay }\end{array}$ & $\begin{array}{c}\text { Concessionaries; mussels growers; } \\
\text { mussels cleaners/scrubbers; } \\
\text { packagers }\end{array}$ & 123 \\
\hline France & Green lentils from Berry & $\begin{array}{c}\text { Farmers; storage silos; } \\
\text { wholesalers-packers; sorting centre }\end{array}$ & 59 \\
\hline France & Pélardon cheese & $\begin{array}{c}\text { Farm and milk producers; } \\
\text { processors; refiners }\end{array}$ & 72 \\
\hline Vietnam & Conical hat from Huế & Processors; producers; traders & 200 \\
\hline Vietnam & Fried calamari from Hạ Long & Producers; traders & 24 \\
\hline Vietnam & Star anise from Lang Sơn & Farmers; processors; collectors; \\
traders
\end{tabular}

Source: Data collected by the authors.

To ensure the representativeness and the balanced representation of the different professional groups involved as required in French law, each ODG has its own rules. In our cases studies, the ODGs have a general assembly that allows stakeholders' participation in decision-making processes. It meets at least once a year to approve financial statements and agree budgets. It is composed of all the members of the ODGs who elect the president from within their number. Decision making is case-dependent. For green lentils from Berry and Bouchot mussels from Mont-St-Michel Bay, decisions are made by a simple majority vote based on a system of weighting of votes that reflects the relative importance of each professional group in terms of volumes of production. For instance, votes in the general assembly of the ODG for green lentils from Berry are distributed among five colleges: (i) Within the producers' college, consensus among producers only is first adopted by a simple majority vote, before one vote is given for each four producers in the general assembly; (ii) within the storage silos' college, each member is entitled to one vote; (iii) within the sorting center's college, each member has one vote per 200 tons of incoming and sorted lentils on a full-year basis; (iv) in the wholesalers-packers' college, each member has a vote; (v) each honorary member has one vote (Statutes of the ODG 'Lentilles vertes du Berry', Articles 9.3). In the general assembly of the ODG for Bouchot mussels from Mont-St-Michel Bay, each member has one vote per ton of PDO mussels produced the previous year with a maximum of 600 votes (Statutes of the ODG 'Moules de Bouchot de la Baie du Mont-Saint-Michel', Article 11). In the ODG for Pélardon, however, each member has a vote, regardless of its weight in terms of volume of production (Statutes of the ODG 'Pélardon', Article 15). 


\subsubsection{State Control and Passive Integration of Local Stakeholders}

Associations in Vietnam are characterized by the strong involvement and control of the state authorities, being subject to a 'unified state management of associations nationwide' under the authority of the Ministry of Home Affairs (Decree 45/2010/ND-CP of 21/04/2010 on the establishment, operation, and management of associations, Articles 1.1 and 36). Producers' associations, when these exist, are usually established by the technical expert in charge of the GI application under the supervision of state authorities and after the GI is registered. This involves the technical expert drawing up the statutes of the producers' association including the membership rules. Among our Vietnamese case studies, it is only for producers of fried calamari from Ha Long that membership in the association has been made a mandatory requirement for being authorized to use the GI (Regulations on the management and use of the GI for fried calamari from Hạ Long, Article 9.7).

One pitfall of this top-down approach to protecting GIs is that the membership rules drafted by the technical expert may exclude some types of stakeholders, resulting in a lack of representation of the different professional groups involved or, conversely, include stakeholders without their consent or knowledge, resulting in a sheer number of members. For instance, as is also the case for Phu Quoc fish sauce, the association of producers of fried calamari from Ha Long excludes fishermen who provide the fresh calamari (Statutes of the association 'Production and commercialisation of fried calamari from Hạ Long', Article 8), even though the quality and origin of the calamari are specified in the specifications as a mandatory standard (Regulations on the management and use of the GI for fried calamari from Hạ Long, Article 9). For both star anise from Lạng Sơn and conical hats from Huế, the producers' associations were established one year after the registration of the GI. Over 700 and 200 members, including farmers, processors, collectors, and traders, were passively integrated into them, respectively (see Table 1). The interviews showed that many of them are not aware of the existence of the association and/or of their own membership. The large number of members in these associations makes it difficult for the association to act as a collaboration platform and for producers to establish close relationships and participate in the decision-making processes.

In Vietnam, in practice, state authorities control the producers' activities through their involvement in the governance and management of the associations, either directly or indirectly. For instance, the president of the association of producers of conical hats from Huê is also the president of the Women's Union at the provincial level, one of the party-State affiliated organizations (so-called 'mass organizations') that are largely funded and controlled by the Communist Party of Vietnam (CPV). In the case of star anise from Lang Sơn, the president of the association is the Secretary of the CPV at the commune level. However, for fried calamari from Hạ Long, producers have gradually taken over the management of the association. If the first president of the producer association was a public official from the District-level Market Control Department (under the authority of the Ministry of Industry and Trade), he was subsequently replaced by the largest producer. The structure of the Vietnamese associations usually includes a general assembly along with a high number of boards and special committees. Yet, unlike in France, the respective importance of the different professional groups is not taken into account in the voting systems or decision-making process.

\subsection{Elaboration Process of the GI Product Specifications}

In line with the national approaches to GI protection in each country, producer or state-driven, the methods used to elaborate the product specifications and the type of issues being addressed are different in each context. In France, their elaboration results from negotiations and reconciliation of different, sometimes conflicting, interests on a range of subjects. In Vietnam, local stakeholders usually have a consultative role on a limited number of topics and always under the umbrella of the State. 


\subsubsection{Negotiations under the Mediation of the State}

In French law, local stakeholders of the value chain lead the elaboration of the product specifications, which are applied by the ODG. This requirement provides local actors with a space to engage in negotiations and discuss their own vision of the product, including its quality, characteristics, and production process, with a view to adopt common standards that formalize, confirm, or modify pre-existing social norms [7]. While it is known that group heterogeneity bears the risk of conflicting interests and longer negotiations [27], our case studies show that negotiations can take several years depending on the nature of the conflicting interests at stake, and may require the intervention of the state authorities, INAO, as mediators when conflicts are too complex. Negotiations and compromises made among local stakeholders may lead to the adoption of higher or looser quality standards, geographical area, and rules of production depending on each GI. The main issues of contention are the choice of the name, the delimitation of the geographical area and the definition of the link between the product and the territory, and the methods of production leading to the specific characteristics of the product.

- Choice of the name

The choice of the name was very disputed among producers of Bouchot mussels from Mont-St-Michel Bay. Some producers opposed the protection process by fear of not being able to comply with the rules and being excluded from the right to use this specific name that they wanted to remain available to all. Negotiations started in the early 1980s and proved so difficult that they stopped between 1996 and 1999. They only started again with the support of INAO as a mediator, who instructed the ODG to register this specific name as it was found to be the oldest and most common name in use in relation to the product since 1956.

- Delimitation of the geographical area and link to the territory

An important point of contention among producers is the delimitation of the geographical area and the definition of the product/origin nexus. For green lentils from Berry, a soil investigation led to the exclusion of bordering areas where soil types were found to be different [28]. For Pélardon cheese, negotiations lasted over 10 years [29]. They mainly focused on the delimitation of the geographical area, the specificity of the cheese and its link to the territory. Negotiations required conducting complementary ethnological surveys and environmental studies. These involved producers, ethnologists, and cheese and livestock technicians [30] while INAO acted as a mediator [31]. It was finally agreed that 500 communes spread over five departments (Specifications 'Pélardon', Article 2), covering a much wider area than the region of origin with a very diverse vegetation, should be included.

In the case of Bouchot mussels from Mont-St-Michel Bay, the negotiations to establish the link to the territory, which stretched over several years, did not involve stakeholders only but also the state authority in charge of registering GIs, in that case the European Commission. This is because the raw materials, i.e., the mussel spats, do not originate from the region of farming but from the neighboring region of Normandy due to the fact that the temperature of the water of the Mont-St-Michel Bay is too low for spats to develop. The specifications are then limited to the steps of farming, preparation, and packaging and do not mention where the larvae must come from (Specifications 'Bouchot mussels from Mt-St-Michel Bay', Article 3). However, they specify that the spats must not be longer than two millimeters to ensure their repatriation to the Bay at the earliest possible time.

- Rules of production and product quality/characteristics

As a consequence of the fact that the GI specifications are elaborated by the producers themselves according to their own strategy, there is a great diversity in terms of the kind of standards encompassed. In the case of Bouchot mussels from Mont-St-Michel Bay, compromises were made on the rules of production, which have allegedly driven the 
product quality towards lower standards. In particular, the French AOC code of practice required that no more than $5 \%$ of mussels should measure less than $3.5 \mathrm{~cm}$, which is considered to be an easy rule to comply with. However, this rule was modified in the European PDO specifications, which now require that less than $20 \%$ of mussels should measure less than $4 \mathrm{~cm}$. Considering that between 60 and $70 \%$ of mussels measure between 3.6 and $3.9 \mathrm{~cm}$, this rule is more difficult to comply with. According to producers, this new rule was decided by the European Commission in an opaque manner without prior consultation of the producers.

By contrast, the production standards of the Pélardon cheese are considered very high as they aim to defend traditional practices. For instance, the prohibition of using mechanical molds and concentrated or powdered milk, as well as the practice of taking goats out on the territory for a minimum number of days, in consistency with traditional pastoral and grazing practices in the area, were made mandatory requirements in the specifications. With respect to the latter, in order to ensure that producers observe agropastoral practices, the quantity of feed concentrate to be distributed to goats is limited to $400 \mathrm{~g}$ per day per liter of goat's milk produced (Technical rules for the implementation of the Specifications 'Pélardon', Article 1 (on file with author)). This strict limit has proved to be too low to support lactation of goats who graze the most on the territory and hence who are provided with very little forage.

\subsubsection{Consultations Organized by the State}

In Vietnam, the fact that actors outside the value chain are primarily responsible for the application process means that local stakeholders of the value chain do not negotiate the rules of the specifications in the construction phase of the initiative. By contrast to French specifications, specifications in Vietnam are elaborated in a few months only. The public authority and the experts might organize some consultations. There is usually no negotiation among the producers during the phase of registration with the national authority in charge of GIs, NOIP, but rather negotiations among the various local public authorities. When consultations with producers are being held, which is not systematic, they may sometimes focus on the rules of production, but they mainly deal with the logo. They do not usually cover the geographical area and the name.

- No consultation

For star anise from Lạng Sơn, the elaboration process of the specifications did not involve consulting local stakeholders. As a result, some stakeholders reported not being aware of their content or of the GI logo itself [32].

- Consultations on the rules of production

In most cases, the consultations involve some categories of stakeholders and their participation is often limited to approving the pre-drafted production rules and the statutes of the association.

Local producers are generally consulted regarding the method of production and characteristics of the product either directly or through their representatives as part of the surveys, data collection, and meetings that the external consultant must organize in the pre-application phase.

For fried calamari from Hạ Long, although producers were first reluctant to come together as a collective due to the fierce competition among them, the process involved several meetings organized by a technical expert in cooperation with the local authorities of the Department of Science and Technology to consult them on the rules of production.

The fact that fishermen were excluded from the consultations tends to confirm that providers of raw materials do not usually participate in the construction phase of the Vietnamese GI initiatives, which may lead to quality control issues [23]. Indeed, a survey found that $50 \%$ of Phu Quoc fish sauce manufacturers believe that quality controls cannot be efficient without the involvement of fishermen [23]. 


\section{- Consultations on the Logo}

By contrast with France, the most active participation and consultation of local stakeholders was found to relate to the choice of the logo associated with the GI. In the case of conical hats from Huế, only the largest traders were consulted by the local authorities of the Department of Science and Technology, and on the choice of the logo alone [33]. For fried calamari from Hạ Long, the design of the logo was also part of the consultations.

- No consultation on the geographical area or the name

The definition of the geographical areas is usually not an issue, as these are based on existing administrative boundaries. The same can be observed with the choice of the name to be protected, which is merely based on the name of the geographical area.

\section{Discussion}

This paper has examined the role of the law in shaping the concept of representativeness in the French bottom-up and Vietnamese state-driven approaches to GI protection. Our case studies confirm the role of the legal and institutional environment in influencing the forms and processes of collective action in each country, in particular with regard to the creation and management of the collectives as well as the elaboration of the rules contained in the product specifications. This section will discuss two main issues arising out of these forms and processes that challenge the concept of representativeness: The contestation or ignorance of the rules included in the GI specifications; and the lack of representativeness of the management systems.

\subsection{Contestation in Producers-Driven Systems or Ignorance of the Rules in State-Driven Systems}

One of the most significant illustrations of the different ways in which the concept of representativeness is understood and applied lies in the methods and processes used to elaborate the product specifications. French law involves interaction, representation, and decision-making processes among all relevant stakeholders. By contrast, Vietnamese law does not contain specific requirements aimed at ensuring producers' representativeness or promoting their collaboration, and external experts have emerged as key players in such processes. Both approaches provide different advantages and disadvantages in each specific context. On the one hand, French local actors strategically initiate the protection process, actively negotiate the pre-existing norms defining the product identity, and manage the GI products in a participatory manner, which has significant consequences for their participation and empowerment. However, the French producers-based system can lead to long and complex negotiations that may result in the adoption of lower or higher quality standards that can continue to be challenged and contested. The registration process can be very long and stretch over several years. On the other hand, the Vietnamese topdown approach can be useful to contribute to the creation of producers' associations and accelerate the registration of GIs in a country where there is little awareness about the GI concept and where local stakeholders lack organizational capacities [34]. The registration process is usually much faster than in France. Yet one common pitfall of top-down processes is the little space, if at all, left to local stakeholders to contribute to the decision-making processes in a meaningful way and take ownership of the GI collectives. In Vietnam, with some exceptions, the top-down approach to GI protection has generally translated in very little understanding, adhesion, and commitment of local actors and hence very little use of the GI labels. Even the fact that GI protection is based on technical rules is not systematically understood, resulting in little focus on how those rules are elaborated. Ultimately, Vietnamese producers, public authorities, and policy-makers tend to see GIs as a commercial logo rather than a sign indicating the product's origin and associated with mandatory technical specifications [35]. 


\subsubsection{Contestation and Opting out of the Rules in the French Case Studies}

Producers-driven systems mean that disputes and objections can arise and last for some time. In the initiatives of Pélardon cheese and Bouchot mussels from Mont-St-Michel Bay, a few producers within the collective are still challenging the rules included in the specifications because they are either considered too strict or too loose, which undermines the quality of collective action and social cohesion within the group.

For Pélardon, the obligation to take goats out on the territory to feed on local herbs for a minimum number of days is opposed by those farmers who produce hay in large quantities and who view this obligation as too burdensome [36]. The prohibition of sale of the cheese before 11 days of maturation after curdling is also being challenged by a few producers who find this rule too difficult to comply with. As a result, many producers have decided to leave the ODG that has 72 members in 2020 down from 120 in 2001 [37].

For Bouchot mussels from Mont-St-Michel Bay, a few members of the ODG believe that production standards are not high enough and that the quality is very uneven across producers [38]. One certified producer has even decided to go beyond the PDO requirements to produce higher-quality mussels with a larger size and higher flesh content, which he promotes on the market with his own trademark over a longer time period than the PDO marketing season. His niche product represents about $15 \%$ of his total production and is sold without the PDO to high-end fishmongers at a price 30\% higher than the PDO mussels, the rest being sold with the PDO [38]. His individual initiative has prompted mixed reactions among PDO producers who believe that this initiative contributes to drive the quality of PDO mussels down [38]. Similar developments have been observed in winemaking in Tuscany. For instance, producers of Chianti wine have opted out of the GI rules to pursue new production methods and introduce non-Tuscan grape varieties into the blends to produce higher-quality wines [39]. This would tend to suggest that, far from 'stifl[ing] competition' [40] (p. 190), GI protection could 'stimulate competition and innovation' [40] (p. 591), possibly at the expense of social cohesion within the GI collective, while questioning the extent to which the norms negotiated during the pre-application phase continue to be representative of the various interests at stake over time.

From that perspective, the case of Camembert de Normandie raises some interesting issues. In 2017, in view of the difference in production volumes between, on the one hand, the PDO Camembert de Normandie that is made out of 50\% raw milk from Norman cows, a particular local breed, grazing at least six months a year in the defined geographical area and, on the other hand, the industrial cheese produced in Normandie made out of pasteurized milk, negotiations were launched under the umbrella of INAO, acting as a mediator, which resulted in an agreement for a new PDO specification (Agreement signed on 21 February 2018 at INAO). However, the agreed amendment to the GI specifications was submitted to a vote of the general assembly of the ODG, which ultimately rejected it (General Assembly of the ODG of 29 January 2020). This outcome leads to consider the legitimacy and representativeness of different groups of producers: Those who were the early members of the 'original' ODG; those who represented the ODG during the negotiations and agreed to the amended specification; and those outside the original PDO who may want to be included. As it may be difficult for these various groups of producers to reach an agreement, the question arises of whether the State should be responsible for defining a common interest. It may be the most impartial approach provided that the consultations with the different groups are fair, representative, and promote the producers' participation and cooperation.

4.1.2. Ignorance of the Rules and Low Use of the GI and Their Associated Labels in the Vietnamese Case Studies

The fact that the specifications are elaborated by outside actors following Vietnam's state-driven top-down approach to GI protection makes it particularly difficult for local producers to understand the GI concept and the rules contained in the GI specifications, take ownership, and participate willingly in the initiatives. A large majority of origin- 
labelling initiatives in Vietnam show little interest and commitment of local actors, as confirmed by our case studies and other recent empirical studies, for instance a study concerning Cao Phong oranges [41]. In analyzing eight case studies in Vietnam, a project funded by the French Agency for Development also found that almost $90 \%$ of producers were not aware that a GI had been registered for their product (NOIP. Rapport-Etude des modèles de gestion des indications géographiques du Vietnam; NOIP/AFD, 2017, p. 56).

This is a particularly serious issue considering that the motivation and commitment of local actors, as well as their coordination and cooperation, have been identified in the GI literature as a main factor of successful GI mobilizations [42]. Top-down approaches, which are still common in many emerging and developing countries, carry the risk that initiatives remain 'purely administrative, without the genuine involvement of producers and with a very low level of use' [7] (p. 53). In practice, there is a significant heterogeneity across Vietnamese initiatives with regard to the right to use. By right of use, we mean formal right of use, recognized by the management organization. For instance, 66 producers (out of 93) [43] and 24 producers (100\% of all producer members of the association) have the right to use the names of Phú Quốc fish sauce and fried calamari from Hạ Long [44], respectively. By contrast, only two companies processing star anise from Lang Son [45], one producer of conical hats from Huế [46], two producers of Cao Phong orange [41,47], and nine companies producing Buon Ma Thuot coffee [22] are entitled to use the GI and its label. Amongst the initiatives where no producer has the right to use the GI are fragrant rice from Nang Nhen Bảy Núi and Văn Yên cinnamon (NOIP (n54), p. 55). Within our case studies, the GI and its logo is used for fried calamari from Hạ Long only.

\subsection{Post-Registration Management by Producers' Organizations in Producers-Driven Systems and by the State in State-Driven Systems}

The forms of management systems, including the institutional mechanisms and voting systems, are important aspects to consider when addressing issues of democratic representation and participation in the internal decision-making processes. In France, questions may arise on the rules governing the ODGs. First, the compulsory membership of all operators has proved controversial as it is contrary to European law, directly applicable in France, which enshrines the principle of availability of PDOs/PGIs by declaring that these may be used by any operator marketing a product conforming to the corresponding specification (Regulation 1151/2012, Article 12.1). This obligation also appears to affect the constitutional freedom of association, including the freedom not to join an association. This appears to be a concern more particularly with regard to the obligation to pay fees (Rural Code, Article L.642-24).

Besides, whereas quorum rules aim to guarantee the proportional representation of members of the ODG in the decision-making processes of the general assemblies, they do not necessarily lead to fairness, as illustrated by the case of Bouchot mussels from Mont-StMichel Bay. According to producers, the heterogeneity among producers in production terms, combined with the growing number of producers who are shareholders of commercial entities, has progressively led to a situation in which the largest producers increasingly control the decisions of the general assemblies, and in particular assert their own economic and commercial interests (or those of the commercial entity they belong to and who also sell non-PDO mussels) over collective issues such as quality of the product [48].

This raises the question of what representativeness truly means and how the quorum rules in the decision-making processes should be designed. Is it fair that representativeness is defined on the basis of the commercial weight or the volume of production? Or should each member have a vote irrespective of economic and production considerations like for Pélardon?

In Vietnam, even if the State can transfer the right to manage GIs to the producers' associations, in practice, the Department of Sciences and Technology and the District People's Committees manage about $70 \%$ and $28 \%$ of existing GIs, respectively [49].The initiative of conical hats from Huế is the only case where the producers' association has the right to manage the GI. Unlike in France, local stakeholders do not have the obligation to 
organize themselves within one association. In practice, a collective organization has been created for about half of the GIs registered so far [50]. The respective importance of the different professional groups is not taken into account in the voting systems or decisionmaking processes of the producers' associations. While this does not automatically mean that the representation of the different professional groups is unbalanced in practice, there is a risk that the functioning of the associations hinders empowerment and participation of local stakeholders while entrenching power imbalances.

\section{Conclusions}

This paper is based on the analysis of two legal frameworks and a variety of empirical case studies. It has evidenced considerable differences between the French producer-led and Vietnamese state-driven approaches to protecting GIs, which are useful to understand how the concept of representativeness is understood and organized in each context. Representativeness varies depending on the respective roles of the state and local stakeholders in the registration process, the management of the initiatives by the collective organizations of producers, and the use of GIs in each country. On the one hand, in Vietnam, there is a lack of collective action among producers, which is evidence of their lack of representativeness by the state authorities. On the other hand, in France, the objective of representativeness may lead to too many conflicts among producers, resulting in delays in the elaboration of the GI specifications. Are there in-between solutions to promote the producers' representation and participation? What is the most suitable role of the State in the elaboration and management of GIs?

Even in producers-led systems, our cases studies and other research show that the issues of representativeness and participation are complex and may be problematic, not only when GI initiatives are established but also in the long run, especially when changes are observed in the value chain, the tastes and choices of consumers, innovation of practices, climate impacts, etc. In this respect, the case of Camembert de Normandie asks an important question: Should one trust the State in defining a common interest? In this initiative, the proposed new specification was negotiated under the auspices of INAO, the French public authority in charge of GIs, who invited a wide range of stakeholders of the value chain to participate in the process. These included even those producers who were not members of the GI producers' association as they did not comply with the specification requiring the use of raw milk but who still represented important volumes of production of a similar (albeit industrial) product sold under a similar name. However, although supported by the State, the proposed amendment was rejected by those producers who had elaborated the initial specification. Does this mean that the State's intervention was not considered legitimate? Is the role of INAO as a mediator enough or should the result of the stakeholders' consultation be enforced especially considering that the stakeholders had not contested at any time that the consultations led by the State were fair and representative? In sharp contrast, in Vietnam, such circumstances would not arise simply because the holding of consultations with representatives of all the stakeholders of the value chain is very rare, and in all cases, the State's proposal would always prevail. The unique situation of Nuoc Mam (fish sauce) from Phu Quoc, which is the only Vietnamese GI that has been registered by the producers' association to date, is the result of a strong cooperation with the European Union and France.

An in-between solution might be that the State organizes a consultation of a wide range of stakeholders, first with a very inclusive approach of the value chain stakeholders, and second with those outside the value chain such as local authority representatives, traders, and possibly also consumers. The representativeness of such consultation would justify that its outcome be applied as a mandatory rule. Another recommendation would be to consider the evolving and dynamic nature of the stakeholders' representativity as is the nature of the GI specification. In this solution, the representativity should be re-examined throughout the long life of the GI, at the request of any stakeholder of the value chain, including those who are not (yet) included in the GI system. However, this solution entails 
that the State is able to check and ascertain the stakeholders' representativity both at the time of examining the GI application and at the time of organizing future consultations. We believe that this should be an essential role of the State as the justice of the peace.

Author Contributions: B.P.: Interviews and data collection for all six case studies, Methodology, Conception and Design, Data analysis and interpretation, Writing-Original draft preparation, reviewing and editing; D.M.-V.: Interviews and data collection for three case studies, Data analysis and inter-pretation, Writing. All authors have read and agreed to the published version of the manuscript.

Funding: This research was funded by the London School of Economics and Political Science (LSE) and the UK Economic and Social Research Council (ESRC).

Informed Consent Statement: Informed consent was obtained from all subjects involved in the study.

Data Availability Statement: The data presented in this study are available on request from the corresponding author. The data are not publicly available due to confidentiality and privacy of the interviewees.

Conflicts of Interest: The authors declare no conflict of interest.

\section{References}

1. Watal, J. Intellectual Property Rights in the WTO and Developing Countries, 1st ed.; Kluwer Law International: Philadelphia, PA, USA, 2001.

2. Vivas-Eugui, D.; Spennemann, C. The Treatment of Geographical Indications in Recent Regional and Bilateral Free Trade Agreements. In The Intellectual Property Debate: Perspectives from Law, Economics and Political Economy; Pugatch, M.P., Ed.; Edward Elgar: Cheltenham, UK, 2006.

3. Blakeney, M. Proposals for the International Regulation of Geographical Indications. J. World Intellect. Prop. 2001, 4, 629-652. [CrossRef]

4. WIPO. World Intellectual Property Indicators 2020. WIPO. 2020. Available online: https://www.wipo.int/edocs/pubdocs/en/ wipo_pub_941_2020.pdf (accessed on 15 February 2021).

5. Bérard, L. Terroir and the sense of place. In Research Handbook on Intellectual Property and Geographical Indications; Dev, S.G., Ed.; Edward Elgar: Cheltenham, UK, 2016; pp. 72-91.

6. Belletti, G.; Marescotti, A. Link Between Origin Labelled Products and Rural Development; Dolphins Final Report; WP3: Bruxelles, Belgium, 2002.

7. Belletti, G.; Marescotti, A.; Touzard, J.-M. Geographical Indications, Public Goods, and Sustainable Development: The Roles of Actors' Strategies and Public Policies. World Dev. 2018, 98. [CrossRef]

8. Vandecandelaere, E.; Arfini, F.; Belletti, G.; Marescotti, A. Linking People, Places and Products: A Guide for Promoting Quality Linked to Geographical Origin and Sustainable Geographical Indications; Food and Agriculture Organization of the United Nations (FAO): Rome, Italy; SINER-GI: Rome, Italy, 2009; p. 220.

9. Quiñones-Ruiz, X.F.; Penker, M.; Belletti, G.; Marescotti, A.; Scaramuzzi, S. Why early collective action pays off: Evidence from setting Protected Geographical Indications. Renew. Agric. Food Syst. 2017, 32, 179-192. [CrossRef]

10. Belmin, R.; Casabianca, F.; Meynard, J.M. Contribution of the transition theory to the study of geographical indications. Environ. Innov. Soc. Trans. 2017, 27, 32-47. [CrossRef]

11. Marie-Vivien, D.; Carimentrand, A.; Fournier, S.; Sautier, D.; Cerdan, C. Controversies around Geographical Indications: Are democracy and representativeness the solution? Br. Food J. 2019, 121, 2995-3010. [CrossRef]

12. Bérard, L.; Marchenay, P. Tradition, regulation and intellectual property: Local agricultural products and foodstuffs in France. In Valuing Local Knowledge: Indigenous Peoples and Intellectual Property Rights; Brush, S.B., Stabinsky, D., Eds.; Island Press: Washington, DC, USA, 1996.

13. Marie-Vivien, D.; Biénabe, E. The Multifaceted Role of the State in the Protection of Geographical Indications: A Worldwide Review. World Dev. 2018, 98, 1-11. [CrossRef]

14. Tregear, A.; Arfini, F.; Belletti, G.; Marescotti, A. The impact of territorial product qualification processes on the rural development potential of small-scale food productions. In Proceedings of the XI World Congress of Rural Sociology, Trondheim, Norway, 25-30 July 2004.

15. Humbert, F. Un parcours et une expertise au sein de l'INAO: Jules Tourmeau. Territoires Du Vin 2009, 1. Available online: https:/ / preo.u-bourgogne.fr/territoiresduvin/index.php?id=1445 (accessed on 19 April 2021).

16. Tregear, A.; Arfini, F.; Belletti, G.; Marescotti, A. Regional foods and rural development: The role of product qualification. J. Rural. Stud. 2007, 23, 12-22. [CrossRef]

17. FAO. Strengthening Sustainable Food Systems Through Geographical Indications; FAO: Rome, Italy, 2018; p. 158. 
18. Quiñones-Ruiz, X.F.; Penker, M.; Belletti, G.; Marescotti, A.; Scaramuzzi, S.; Barzini, E.; Pircher, M.; Leitgeb, F.; Samper-Gartner, L.F. Insights into the black box of collective efforts for the registration of Geographical Indications. Land Use Policy 2016, 57, 103-116. [CrossRef]

19. Paus, M.; Réviron, S. Crystallisation of Collective Action in the Emergence of a Geographical Indication System. In Proceedings of the 116th EAAE Seminar "Spatial Dynamics in Agrifood Systems: Implications for Sustainability and Consumer Welfare", Parma, Italy, 27-30 October 2010; 2010.

20. Sautier, D.; Bienabe, E.; Cerdan, C. Geographical indications in developing countries. In Labels of Origin for Food: Local Development, Global Recognition; Elizabeth Barham, B.S., Ed.; CABI: Wallingford, UK, 2011; pp. 139-153.

21. Biénabe, E.; Marie-Vivien, D. Institutionalizing Geographical Indications in Southern Countries: Lessons Learned from Basmati and Rooibos. World Dev. 2018, 98, 58-67. [CrossRef]

22. Durand, C.; Fournier, S. Can Geographical Indications Modernize Indonesian and Vietnamese Agriculture? Analyzing the Role of National and Local Governments and Producers' Strategies. World Dev. 2018, 98, 93-104. [CrossRef]

23. Marie-Vivien, D. Protection of Geographical Indications in ASEAN countries: Convergences and challenges to awakening sleeping Geographical Indications. J. World Intellect Prop. 2020, 23, 328-349. [CrossRef]

24. Belletti, G.; Marescotti, A. Origin Products, Geographical indications and Rural Development. In Geographical Indications and Globalisation in Agro-Food Supply Chains; Sylvander, B., Barham, E., Eds.; CABI: Wallingford, UK, 2011 ; pp. 75-91.

25. Réviron, S.; Chapuis, J.-M. Geographical Indications: Collective Organisation and Management. In Labels of Origin for Food: Local Development, Global Recognition; Barham, E., Sylvander, B., Eds.; CABI: Wallingford, UK, 2011; pp. 45-62.

26. Pick, B. President of the ODG, Interview in Person. Issoudun, France. August 2014.

27. Dentoni, D.; Menozzi, D.; Capelli, M.G. Group heterogeneity and cooperation on the geographical indication regulation: The case of the "Prosciutto di Parma" Consortium. Food Policy 2012, 37, 207-216. [CrossRef]

28. Pick, B. Commercial Director, E-mail received on 13 July 2018.

29. Pick, B. Coordinator of the ODG, Telephone Interview. July 2014.

30. Pick, B. Coordinator of the ODG, Phone interview. July 2014.

31. Pick, B. INAO Territorial Delegate, Telephone interview. December 2014.

32. Pick, B.; Marie-Vivien, D. Producers, Interviews in Person. Lạng Sơn, Vietnam. May 2014.

33. Pick, B.; Marie-Vivien, D. Producers, Interviews in Person. Huế, Vietnam. April 2014.

34. Quiñones-Ruiz, X.F.; Penker, M.; Belletti, G.; Marescotti, A.; Scaramuzzi, S. Why Early Collective Action Pays off: Evidence from Setting Protected Geographical Indications. Cambridge University Press: Cambridge, UK, 2016.

35. Marie-Vivien, D.; Pick, B. Geographical Indications and Trademarks in Vietnam: Confusion or Real Difference? Agriculture in an Urbanizing Society: Rome, Italy, 2015; pp. 151-153.

36. Napoléone, M.; Boutonnet, J.P. AOC Pélardon: du compromis vers l'émergence d'actions collectives. Dynamiques de systèmes de production et des stratégies de commercialisation. In Proceedings of the Séminaire SFER, Les Systèmes de Production Agricoles: Performances, Evolutions, Perspective, Lille, France, 17-18 November 2004.

37. Pick, B. Coordinator of the ODG, E-mail received on 17 July 2020.

38. Pick, B. Producers, Interviews in Person. Vivier-sur-Mer, France. August 2014.

39. Broude, T. Taking Trade and Culture Seriously: Geographical Indications and Cultural Protection in WTO Law. U. Pa. J. Int'l Econ. L. 2005, 26, 623-692. [CrossRef]

40. Agdomar, M. Removing the Greek From Feta and Adding Korbel to Champagne: The Paradox of Geographical Indications in International Law. Fordham Intellect. Prop. Media Entertain. Law J. 2008, 18, 541-608.

41. Alexandre, C. Impacts et perspectives de développement de l'indication géographique Orange de Cao Phong; Spécialité MOQUAS, IRC de spécialité, Montpellier SupAgro: Montpellier, France, 2017.

42. Barjolle, D.; Sylvander, B. Some factors of success for "origin labelled products" in Agro-food supply chains in Europe: Market, Internal Resources and Institutions. Écon. Soc. 2002, 25, 1441. [CrossRef]

43. Nguyen, T.; Hoang, G.; Nguyen, K. Geographical Indications and Quality Promotion of Agricultural Products in Vietnam: An Analysis of Government Roles; SECO/WTI Academic Cooperation Project Working Paper Series; SECO/WTI Academic Cooperation Project: Bern, Switzerland, 2016.

44. Pick, B.; Marie-Vivien, D. President of the producers' association, Interview in Person. Hạ Long, Vietnam. April 2017.

45. Pick, B. Producers, Telephone interviews. October 2020.

46. Pick, B. Director, Department of Science and Technology, Telephone interview. September 2020.

47. Hoang, G.; Le, H.T.T.; Nguyen, A.H.; Dao, Q.M.T. The Impact of Geographical Indications on Sustainable Rural Development: A Case Study of the Vietnamese Cao Phong Orange. Sustainability 2020, 12, 4711. [CrossRef]

48. Pick, B. Producers, Telephone interviews. July 2018.

49. Duc Chien, C.; Dong, B.K.; Marie-Vivien, D. Placing value chain stakeholders at the core of Geographical Indication in Vietnam. In Malica Policy Brief; Cirad/Malica: Hanoi, Vietnam, 2018.

50. Durand, C. L'emergence Des Indications Geographiques Dans Les Processus De Qualification Territoriale Des Produits AgroalimentairesUne Analyse Comparee Entre L'indonesie Et Le Vietnam; Institut national d'études supérieures agronomiques de MontpellierSupAgro Montpellier: Montpellier, France, 2016. 